\title{
ADD3 Gene
}

National Cancer Institute

\section{Source}

National Cancer Institute. ADD3 Gene. NCI Thesaurus. Code C80077.

This gene plays a role in cytoskeletal assembly. 